Scientific Review - Engineering and Environmental Sciences (2017), 26 (3), 326-335

Sci. Rev. Eng. Env. Sci. (2017), 26 (3)

Przegląd Naukowy - Inżynieria i Kształtowanie Środowiska (2017), 26 (3), 326-335

Prz. Nauk. Inż. Kszt. Środ. (2017), 26 (3)

http://iks.pn.sggw.pl

DOI 10.22630/PNIKS.2017.26.3.32

\title{
Grzegorz WAŁEK
}

Instytut Geografii, Uniwersytet Jana Kochanowskiego w Kielcach

Institute of Geography, Jan Kochanowski University in Kielce

\section{Wykorzystanie metod GIS do wyznaczania działów wodnych zlewni zurbanizowanych na przykładzie miasta Kielce The use of GIS methods in urban catchment drainage divides delineation on example of the Kielce city}

Słowa kluczowe: zlewnia zurbanizowana, wyznaczanie granic zlewni, GIS

Key words: urbanized catchment, drainage divides delineating, GIS

\section{Wprowadzenie}

Zlewnie topograficzne to podstawowe jednostki (systemy) przestrzenne w opracowaniach hydrologicznych (Gutry-Korycka i Soczyńska, 1990), w tym $\mathrm{W}$ wielu pracach $\mathrm{z}$ zakresu inżynierii i gospodarki wodnej. Wyznaczenie ich zasięgu jest pierwszym krokiem w kierunku ustalenia parametrów fizjograficznych takich jak powierzchnia, długość czy średni spadek zlewni. Parametry te warunkują wyniki obliczeń hydrologicznych i hydraulicznych, a dokładność ich wyznaczenia jest szczególnie istotna w analizach małych zlewni miejskich.

W obszarach silnie zurbanizowanych, a przez to - uszczelnionych
- zlewni miejskich następują znaczne modyfikacje powierzchniowego systemu obiegu wody. Jednym z ich przejawów są zmiany przebiegu powierzchniowych działów wodnych zlewni miejskich, które wpływają na parametry fizjograficzne tych zlewni (Czaja 1999; Wałek, 2014a). Ich przyczyną są sztucznie projektowane sieci drenażu (rowy melioracyjne, kanalizacja deszczowa lub ogólnospławna, drogi i ich odwodnienie), a także antropogeniczne zmiany rzeźby terenu (Wałek, 2012, 2014b). Wszystkie wymienione czynniki modyfikują naturalne kierunki spływu wody w obszarach miast, co ostatecznie wpływa na zmiany kształtu i powierzchni zlewni topograficznych.

Wyznaczenie aktualnego, rzeczywistego przebiegu powierzchniowych działów wodnych w zlewniach zurbanizowanych jest we współczesnej praktyce hydrologicznej ważnym problemem metodologicznym. Duża dokładność 
wyznaczenia powierzchni zlewni jest bowiem niezbędna do bilansowania zasobów wodnych małych zlewni miejskich, obliczania przepływów i ładunków transportowanych zanieczyszczeń, wymiarowania i obliczania obciążeń kanalizacji lub ustalania zasięgu stref zalewowych czy też możliwości wystąpienia podtopień.

\section{Hipoteza i cel pracy}

Analizy hydrologiczne małych zlewni, których powierzchnie zgodnie z tzw. Ramową dyrektywą wodną (2000) wynoszą od 10 do $100 \mathrm{~km}^{2}$, oraz mniejszych zlewni cząstkowych wymagają najbardziej szczegółowych danych - między innymi dotyczących zasięgu zlewni topograficznych. Postawiono hipotezę, iż precyzyjne wyznaczanie rzeczywistego przebiegu powierzchniowych działów wodnych niewielkich zlewni miejskich jest możliwe w środowisku GIS z wykorzystaniem istniejących numerycznych modeli terenu (NMT) oraz dokładnych informacji o przebiegu istniejącej naturalnej i antropogenicznej sieci drenażu w formie cyfrowych wektorowych baz danych przestrzennych.

Celem prezentowanej pracy jest analiza wpływu różnych danych źródłowych (w tym: cyfrowych danych przestrzennych ukazujących ukształtowanie terenu oraz naturalną i antropogeniczną sieć drenażu, mapy topograficznej w skali $1: 10000$ oraz mapy podziału hydrograficznego Polski - MPHP w skali $1: 10000$ ), na wyniki wyznaczania powierzchni oraz zasięgu małych zlewni w obszarach zurbanizowanych na przykładzie miasta Kielce. Ten nadrzędny cel pracy został zrealizowany poprzez dwa cele szczegółowe:

1. Ocena różnic powierzchni oraz zasięgu zlewni rzeki Silnicy wyznaczonej na podstawie dostępnych tradycyjnych danych źródłowych (mapa topograficzna $1: 10$ 000; mapa podziału hydrograficznego Polski $1: 10$ 000) oraz trzech wariantów modelowania kierunków spływu powierzchniowego w GIS.

2. Ocena różnic powierzchni i zasięgu sześciu zlewni cząstkowych rzeki Silnicy wyznaczonych na podstawie trzech wariantów modelowania kierunków spływu powierzchniowego w GIS.

Tematyka podjęta $\mathrm{W}$ niniejszej pracy koresponduje $\mathrm{z}$ badaniami innych autorów, którzy zauważajac, że automatyczny proces wyznaczania granic zlewni na podstawie dostępnych danych w GIS może być obarczony znacznymi błędami wynikającymi z pominięcia w analizie specyfiki obiegu wody na badanym obszarze (Khan, Richards, Parker, McRobie i Mukhopadhyay, 2014). Z tej przyczyny przeprowadzono trzy warianty modelowania kierunków spływu wody w GIS, które szczegółowo opisano w części metodycznej pracy.

\section{Obszar badań}

Analizę przebiegu powierzchniowych działów wodnych przeprowadzono na przykładzie zlewni rzeki Silnicy (V rząd) o powierzchni $48 \mathrm{~km}^{2}$ (MPHP $1: 10000)$ oraz znajdujących się w jej centralnej części sześciu zlewni cząstkowych, które jednocześnie położone są w centrum Kielc (rys. 1). Współcześnie zlewnie te mają charakter zlewni kanałowych pokrytych gęstą siecią dróg i zabu- 


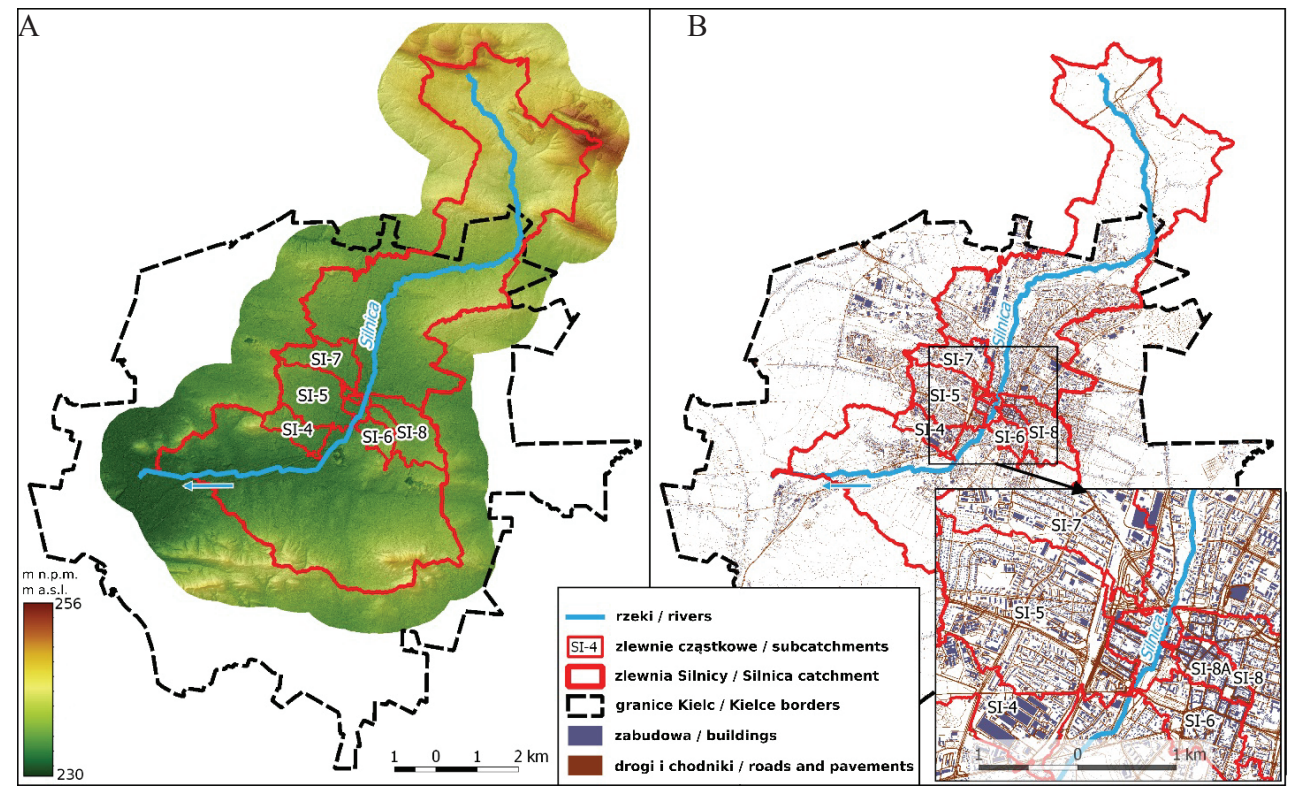

RYSUNEK 1. Obszar badań na tle rzeźby terenu (A) oraz zabudowy i sieci drogowej (B)

FIGURE 1. Research area on the background of terrain relief (A), buildings and road network (B)

dową. Ich nazwy zaczerpnięto z opracowań dotyczących kanalizacji deszczowej w Kielcach. Badany obszar znajduje się w zachodnim krańcu Wyżyny Kieleckiej. Rzeźbę terenu Kielc charakteryzuje amfiteatralny układ wzniesień, co spowodowało koncentrację dróg spływu wód opadowych w kierunku centrum miasta (Ciupa, 2009; Ciupa i Wałek, 2013).

\section{Material}

W niniejszej pracy wykorzystano numeryczny model terenu (NMT) o strukturze GRID i rozdzielczości przestrzennej $1 \mathrm{~m}$, wykonany w ramach projektu Informatycznego systemu osłony kraju przed nadzwyczajnymi zagrożeniami (ISOK) na podstawie chmury punktów, którą pozyskano z lotniczego skaningu laserowego $\mathrm{z}$ dokładnością 12 punk- tów na $1 \mathrm{~m}^{2}$. Numeryczny model terenu przedstawia rzeczywiste ukształtowanie powierzchni terenu nawet pod pokrywą roślinną (Wężyk, 2015). Informacje dotyczące przebiegu naturalnej sieci rzecznej, rowów melioracyjnych i kanałów otwartych pozyskano z bazy danych obiektów topograficznych (BDOT) w skali $1 \quad$ : $10 \quad 000 \quad$ (BDOT 10k) z 2014 roku (Rozporządzenie Ministra Spraw Wewnętrznych i Administracji z dnia 17 listopada 2011 r.). Wykorzystano warstwy wektorowe $\mathrm{z}$ grupy klas obiektów przestrzennych reprezentujących sieć wodną: SWRS (rzeki i strumienie), $S W K N$ (kanały) oraz SWRM (rowy melioracyjne). Z geodezyjnej ewidencji sieci uzbrojenia terenu - GESUT (Rozporządzenie Ministra Administracji i Cyfryzacji z dnia 12 lutego 2013 r.) pozyskano dane o charakterze i przebiegu sieci kanalizacyjnej w Kielcach 
w 2015 roku. Wykorzystano następujące klasy obiektów: SUPKO1 (przewód kanalizacyjny deszczowy) oraz SUPKO3 (przewód kanalizacyjny ogólnospławny). W celu wyznaczenia przebiegu powierzchniowych działów wodnych metodą tradycyjną na podstawie rysunku poziomicowego wykorzystano arkusze mapy topograficznej w skali 1 : 10000 w układzie 1992. Modelowane w GIS zasięgi zlewni porównano także $\mathrm{z}$ odpowiadającymi im zasięgami zawartymi w wektorowej bazie danych mapy podziału hydrograficznego polski (MPHP) w skali 1 : 10000 udostępnionej przez Krajowy Zarząd Gospodarki Wodnej.

\section{Metodyka}

Procedurę badawczą przeprowadzono z użyciem oprogramowania SAGA GIS. Do modelowania kierunków spływu wody umożliwiającego wyznaczenie przebiegu powierzchniowych działów wodnych (z użyciem NMT i danych wektorowych opisujących przebieg rzeczywistej sieci drenażu) wykorzystano metodę deterministyczną - D8 (ang. Deterministic 8) (O'Callaghan i Mark, 1984), której założeniem jest modelowanie spływu wody między komórkami rastra NMT w kierunku największego spadku terenu (rys. 2).

W celu umożliwienia modelowania kierunków spływu przeprowadzono preprocessing NMT, którego procedura składała się z dwóch etapów:

- obniżenia wartości komórek NMT położonych w miejscach przebiegu istniejącej sieci drenażu w celu zapewnienia modelowania spływu powierzchniowego $\mathrm{w}$ rzeczywistych

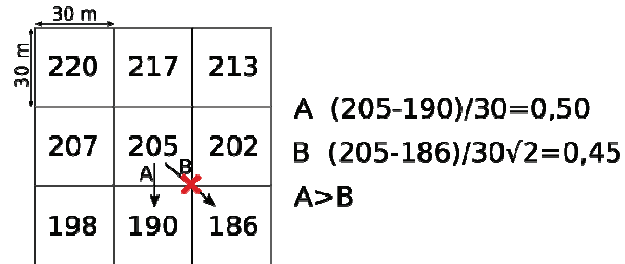

RYSUNEK 2. Założenia metody D8 (liczby w komórkach oznaczają wysokość w m n.p.m., symbole A i B oznaczają gradient spadku terenu w dwóch rozpatrywanych kierunkach, 30-metrową wielkość komórki przyjęto wyłącznie dla celów poglądowych)

FIGURE 2. The D8 method assumptions (the numbers in cells refer to elevation in meters a.s.l., $\mathrm{A}$ and $\mathrm{B}$ symbols refer to slope gradients in two analyzed directions, 30-meter cell size is for illustrative purposes only)

kierunkach (wykorzystano linie sieci drenażu z warstw tematycznych baz BDOT 10k i GESUT);

- tzw. wypełnienia zagłębień bezodpływowych w NMT mających zapewnić ciagłość modelowania spływu. Operację tą przeprowadzono metodą Wanga i Liu (2006), która zalecana jest zwłaszcza w przypadku szczegółowych NMT o dużej objętości, takich jak NMT z projektu ISOK.

Aby zrealizować cel pracy, przygotowano trzy warianty numerycznego modelu terenu:

- NMT przygotowany do generowania granic zlewni z wykorzystaniem poprawionych topologicznie i uzupełnionych linii rzeczywistej sieci drenażu $\mathrm{z}$ baz danych BDOT 10k i GESUT;

- NMT przygotowany z wykorzystaniem oryginalnych warstw z BDOT 10k i GESUT (bez poprawek i uzupełnień);

- NMT przygotowany z wykorzystaniem tylko powierzchniowej sieci drenażu z bazy BDOT 10k. 
Powstałe NMT poddano analizie kierunków spływu - D8, której wyniki umożliwiły wyznaczenie przebiegu topograficznych działów wodnych Silnicy i jej sześciu zlewni cząstkowych. Powierzchnie oraz zasięgi wygenerowanych zlewni poddano analizie porównawczej, w której wykorzystano także zlewnie wyznaczone $\mathrm{z}$ mapy topograficznej w skali 1 : 10000 oraz z MPHP w skali 1 : 10 000. Warto zauważyć (za Barszczyńską i in., 2013), że podstawowym źródłem danych do utworzenia warstwy granic zlewni elementarnych w MPHP 1 : 10000 był NMT w postaci GRID o rozdzielczości $5 \mathrm{~m}$ wykonany W ramach projektów LPIS ze zdjęć lotniczych w skalach 1 : 13000 i 1 : 26000 , a w obszarach zalesionych - mapa topograficzna w skali 1: 10 000. Sa to materiały charakteryzujące się dużo mniejszą dokładnością i szczegółowością niż NMT z projektu ISOK wykorzystany $\mathrm{W}$ niniejszej pracy.

\section{Wyniki}

W pierwszej kolejności porównano ze sobą trzy warianty zasięgu zlewni Silnicy wygenerowanie $\mathrm{z}$ użyciem metod GIS (rys. 3A). Pole powierzchni zlewni Silnicy wyznaczone z wykorzystaniem skorygowanych i uzupełnionych baz BDOT i GESUT wyniosło $48,599 \mathrm{~km}^{2}$ (rys. 3A1). Pozostałe dwa wygenerowane pola powierzchni zmieniały się w granicach od 48,375 $\mathrm{km}^{2}$ w wariancie, w którym wykorzystano oryginalne, nieskorygowane bazy BDOT i GESUT (rys. 3A2), do 51,129 km² $\mathrm{W}$ wariancie $\mathrm{z}$ wykorzystaniem tylko bazy BDOT (rys. 3A3). Zasięg zlewni Silnicy wygenerowanej z użyciem skorygowanych baz danych BDOT i GESUT w pełni pokrył się z funkcjonującymi kierunkami odwodnienia w postaci koryt otwartych i z sieci kanalizacyjnej. Przyjęto go za podstawę odniesienia. Różnice $\mathrm{W}$ porównaniu $\mathrm{z}$ innymi wariantami

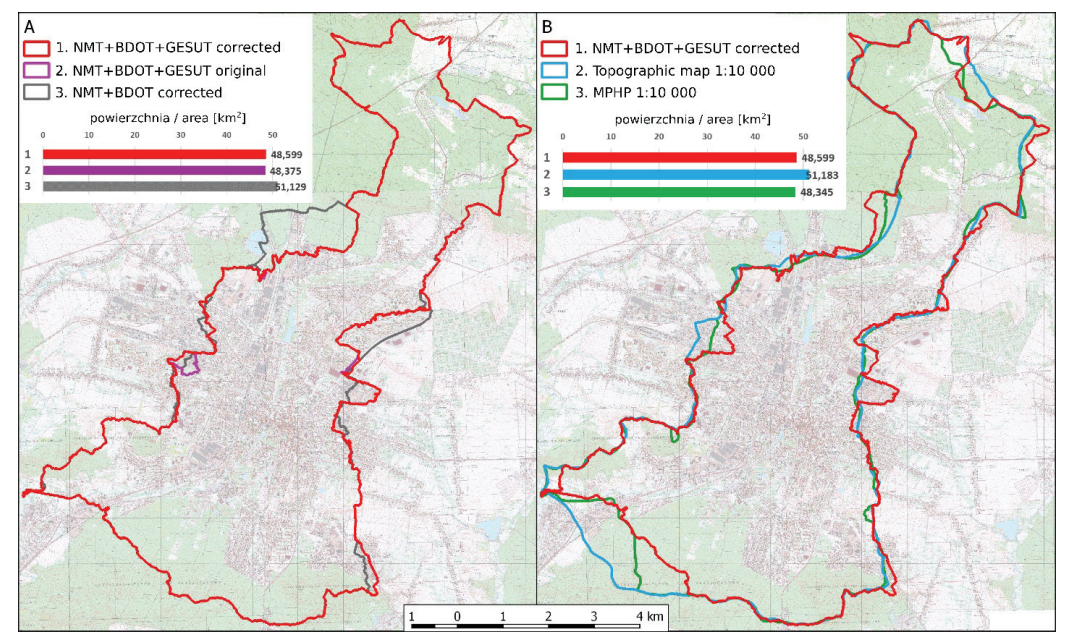

RYSUNEK 3. Porównanie zasięgu zlewni rzeki Silnicy wyznaczonego różnymi metodami FIGURE 3. Comparison of the Silnica river catchment area determined with different methods 
wyniosły $-0,46 \%$ dla zlewni wygenerowanej z wykorzystaniem nieskorygowanych baz danych oraz $+5,2 \%$ w stosunku do wariantu z samą bazą BDOT. $\mathrm{W}$ wariancie $\mathrm{z}$ wykorzystaniem mapy topograficznej w skali 1 : 10000 i MPHP w skali $11: 10000$ (rys. 3B) największą powierzchnię osiagnnęła zlewnia wyznaczona na podstawie mapy topograficznej $-51,183 \mathrm{~km}^{2}$ (rys. 3B2), a najmniejsza zlewnia z MPHP - 48,345 $\mathrm{km}^{2}$ (rys. 3B3). W tym przypadku różnice wyniosły $+5,31 \mathrm{w}$ odniesieniu do zasięgu $\mathrm{z}$ mapy topograficznej $\mathrm{i}-0,52 \% \mathrm{w}$ stosunku do MPHP.

W dalszym etapie badań porównano ze sobą zasięgi sześciu zlewni cząstkowych, wygenerowane $\mathrm{z}$ użyciem trzech wariantów NMT i metod GIS (rys. 4). $\mathrm{W}$ tej części analizy nie wykorzystano mapy topograficznej, ponieważ rysunek poziomicowy w centrum miasta nie był widoczny. Na MPHP w skali $1: 10000$ również nie odnaleziono zasięgów analizowanych zlewni. Warianty zlewni cząstkowych wyznaczone z wykorzystaniem skorygowanych baz danych BDOT i GESUT okazały się w pełni zgodne z rzeczywistymi kierunkami odwodnienia. Największe zmiany powierzchni wystapiły w przypadku zlewni SI-7, gdzie różnica między wariantem z oryginalnymi bazami danych BDOT i GESUT $\left(1,283 \mathrm{~km}^{2}\right)$ a powierzchnią zlewni wygenerowaną tylko z użyciem bazy BDOT $\left(1,831 \mathrm{~km}^{2}\right)$ wyniosła $0,548 \mathrm{~km}^{2}$. Wersja zasięgu tej zlewni wyznaczonej z wykorzystaniem tylko BDOT okazała się być o $34,85 \%$ większa w stosunku do powierzchni wyznaczonej z użyciem skorygowanych baz danych. Stosunkowo największe różnice wystapiły w przypadku zlewni SI-8A, gdzie zasięg wygenerowany z użyciem BDOT $\left(0,054 \mathrm{~km}^{2}\right)$ był aż o $77,50 \%$ mniejszy od rzeczywistej powierzchni tej zlewni

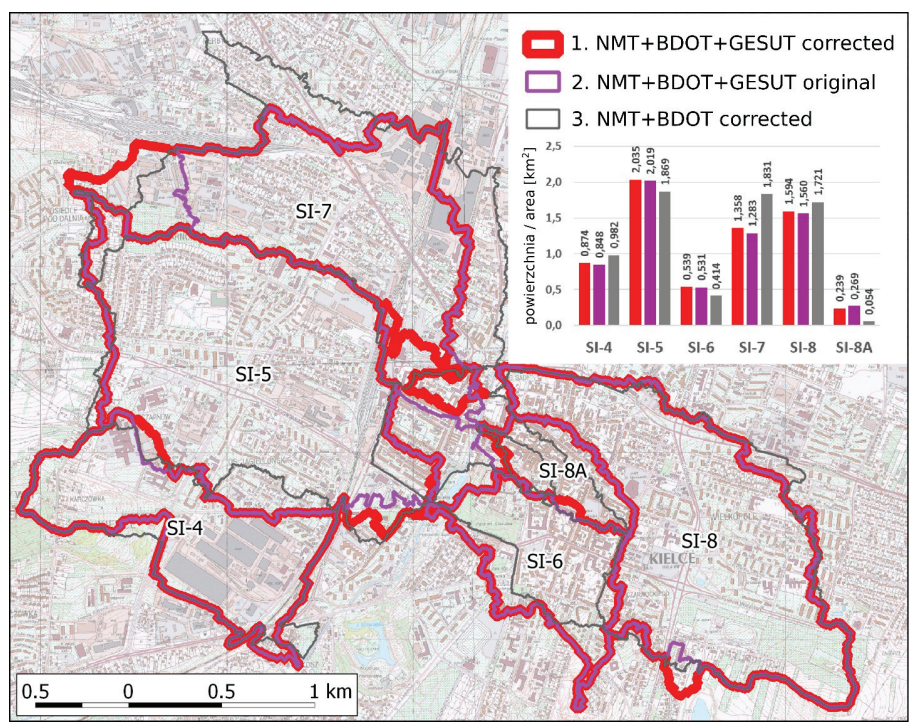

RYSUNEK 4. Porównanie zasięgów zlewni cząstkowych rzeki Silnicy wyznaczonych różnymi metodami

FIGURE 4. Comparison of the Silnica river subcatchments reach determined with different methods 
$\left(0,239 \mathrm{~km}^{2}\right)$. We wszystkich analizowanych przypadkach różnice między rzeczywistymi powierzchniami badanych zlewni i ich odpowiednikami wyznaczonymi z użyciem oryginalnych baz danych BDOT i GESUT (min. $-0.81 \%$, maks. $+12,22 \%$ ) były znacznie mniejsze od różnic między rzeczywistymi zasięgami zlewni a tymi wyznaczonymi z użyciem jedynie bazy BDOT (min. $+7,98 \%$, maks. $-77,50 \%$ ).

\section{Podsumowanie i wnioski}

Zasięgi badanych zlewni wygenerowane z użyciem NMT oraz skorygowanych baz danych BDOT i GESUT pokryły się z rzeczywistymi naturalnymi i antropogenicznymi kierunkami odwodnienia - wygenerowane powierzchniowe działy wodne nie przecięły żadnego z odcinków istniejącej sieci drenażu.

Różnice powierzchni zlewni Silnicy wyznaczonej na podstawie mapy topograficznej w skali 1 : 10000 oraz MPHP w skali 1 : $10000 \mathrm{w}$ porównaniu z zasięgami wygenerowanymi w GIS z wykorzystaniem modelowania hydrologicznego osiagnęly maksymalnie 5,31\% (2,584 $\left.\mathrm{km}^{2}\right)$. Miejsca zmian przebiegu powierzchniowego działu wodnego tej zlewni różniły się wyraźnie w każdym wariancie. Największe przesunięcia nastapiły na terenach zalesionych w północnej i południowej części zlewni oraz w centrum miasta, gdzie kanalizacja deszczowa wymusza kierunki odwodnienia. Porównując zlewnię Silnicy wygenerowaną z użyciem metod GIS oraz skorygowanych baz danych BDOT i GESUT z zasięgiem z MPHP w skali $1: 10$ 000, można zauważyć, że różnica w areale zlewni jest znikoma, zmianom natomiast uległ przebieg granic zlewni. Obszary znajdujące się w zasięgu tych zmian charakteryzują się odmiennym pokryciem i użytkowaniem.

W przypadku zasięgów i powierzchni analizowanych zlewni cząstkowych wyznaczonych z wykorzystaniem GIS największa różnica między rzeczywistą powierzchnią zlewni a powierzchnią wygenerowaną z użyciem jedynie NMT i BDOT osiągnęła-77\% (SI-8A). Różnice między powierzchniami zlewni cząstkowych wygenerowanymi z użyciem nieskorygowanych baz BDOT i GESUT były niewielkie, jedynie w przypadku zlewni SI-8A przekroczyły 10\%. Miejsca zmian przebiegu powierzchniowych działów wodnych różniły się znacznie w każdym wariancie, skutkując zmianami zasięgu przestrzennego badanych zlewni.

Numeryczne modele terenu oraz skorygowane bazy danych BDOT i GESUT okazały się być niezbędne do wyznaczenia prawidłowego zasięu badanych zlewni, a w szczególności małych zlewni cząstkowych w centrum miasta. Sieć wodna w bazie danych BDOT oraz kanalizacja deszczowa w bazie danych GESUT były obarczone błędami topologicznymi i brakami, których poprawa i uzupełnienie wpłynęły na polepszenie wyników modelowania zasięgów zlewni miejskich. Mimo to wykorzystanie nawet nieskorygowanej bazy GESUT znacznie poprawiło wyniki modelowania zasięgu zlewni w porównaniu do wariantu z samą bazą BDOT.

Mapa topograficzna w skali 1: 10000 oraz MPHP w skali 1 : 10000 okazały się być niewystarczające do wyznaczenia zasięgu badanych zlewni cząstkowych, 
a powierzchnia i zasięg zlewni rzeki Silnicy wyznaczone na ich podstawie odbiegały w dużej mierze od zasięgu rzeczywistego wygenerowanego z użyciem NMT oraz skorygowanych baz BDOT i GESUT.

Uzyskane wyniki wskazująna potrzebę wykorzystania w praktyce inżynierskiej informacji dotyczących przebiegu antropogenicznej sieci odwodnieniowej w formie rowów melioracyjnych, kanałów otwartych oraz w szczególności sieci kanalizacji deszczowej i ogólnospławnej w preprocessingu numerycznych modeli terenu, na podstawie których można wyznaczyć rzeczywisty przebieg topograficznych działów wodnych małych zlewni zurbanizowanych. Zaznaczyć należy, że w każdym z wariantów przeprowadzonego modelowania zmianom ulegały zarówno areał badanych zlewni, jak i ich zasięg przestrzenny. W przypadku niektórych zlewni takie zmiany ich przestrzennego zasięgu - będące wynikiem różnych metod wyznaczania granic zlewni oraz różnej jakości danych źródłowych, pomimo nawet podobnych wartości uzyskiwanych powierzchni - mogą mieć znaczący wpływ na wielkość ustalanych współczynników odpływu na cele modelowania hydrologicznego. Powodem tego jest odmienna struktura pokrycia terenu w wyznaczonych obszarach zlewni. Zagadnienie to wymaga dalszych badań.

\section{Literatura}

Barszczyńska, M., Borzuchowski, J., Kubacka, D., Piórkowski, P., Rataj, C., Walczykiewicz, T. i Woźniak, Ł. (2013). Mapa Podziału Hydrograficznego Polski w skali 1:10 000
- nowe hydrograficzne dane referencyjne. Roczniki Geomatyki, 11, 3(60), 15-28.

Ciupa, T. (2009). Wplyw zagospodarowania terenu na odplyw $i$ transport fluwialny $w$ matych zlewniach na przykładzie Sufragańca i Silnicy (Kielce). Kielce: Wydawnictwo UJK.

Ciupa, T. i Wałek G. (2013). Zastosowanie kartografii porównawczej i technik GIS do analizy wpływu rzeźby terenu na przestrzenne zmiany zabudowy Kielc od początku XIX w. do 2010 r. W B. Medyńska-Gulij i J. Kubiak (red.), Pragmatyka $w$ kartografii. (strony 15-29). Poznań: Bogucki Wydawnictwo Naukowe.

Czaja, S. (1999). Zmiany stosunków wodnych $w$ warunkach silnej antropopresji. Katowice: Wydawnictwo UŚ.

Dyrektywa 2000/60/WE (Ramowa Dyrektywa Wodna) Parlamentu Europejskiego i Rady z dnia 23 października 2000 r. w sprawie ustanowienia ram działalności Wspólnoty $w$ dziedzinie polityki wodnej. Dz.U.UE L.00.327.1, 22.12.2000.

Gutry-Korycka, M. i Soczyńska, U. (1990). Cykl hydrologiczny zlewni. W U. Soczyńska (red.), Podstawy hydrologii dynamicznej. (strony 14-44). Warszawa: Wydawnictwo UW.

Khan, A., Richards, K.S., Parker, G.T., McRobie, A. i Mukhopadhyay, B. (2014). How large is the Upper Indus Basin? The pitfalls of auto-delineation using DEMs. Journal of Hydrology, 509, 442-453.

O'Callaghan, J.F. i Mark, D.M. (1984). The extraction of drainage networks from digital elevation data. Computer Vision, Graphics and Image Processing, 28, 323-344.

Rozporzadzenie Ministra Administracji $i$ Cyfryzacji z dnia 12 lutego 2013 r. w sprawie bazy danych geodezyjnej ewidencji sieci uzbrojenia terenu, bazy danych obiektów topograficznych oraz mapy zasadniczej. Dz.U. 2013 poz. 383 .

Rozporzadzenie Ministra Spraw Wewnętrznych $i$ Administracji z dnia 17 listopada 2011 r. $w$ sprawie bazy danych obiektów topograficznych oraz bazy danych obiektów ogólnogeograficznych, a takze standardowych opracowań kartograficznych. Dz.U. 2011 nr 279, poz. 1642 . 
Wałek, G. (2012). Współczesne przeobrażenia rzeźby na terenie Kielc. Landform Analysis, 19, 81-90.

Wałek, G. (2014a). Rola dróg w kształtowaniu kierunków spływu powierzchniowego w zlewniach miejskich na przykładzie Kielc. W T. Ciupa, R. Suligowski (red.), Woda $w$ mieście, Monografie Komisji Hydrologicznej PTG, t. 2 (strony 301-310). Kielce: Instytut Geografii UJK.

Wałek, G. (2014b). Wpływ zagospodarowania terenu na zmiany przebiegu topograficznych działów wodnych w małych zlewniach miejskich na przykładzie Kielc. W A. Magnuszewski (red.), Hydrologia $w$ ochronie $i$ ksztaltowaniu środowiska, Monografie Komitetu Gospodarki Wodnej PAN, 22, 2 (strony 143-153). Warszawa: PAN.

Wang, L. i Liu, H. (2006). An efficient method for identifying and filling surface depressions in digital elevation models for hydrologic analysis and modelling. International Journal of Geographical Information Science, 20(2), 193-213.

Wężyk, P. (2015). Podręcznik dla uczestników szkoleń z wykorzystania produktów LiDAR. Warszawa: GUGiK.

\section{Streszczenie}

Wykorzystanie metod GIS do wyznaczania działów wodnych zlewni zurbanizowanych na przykladzie miasta Kielce. $\mathrm{W}$ pracy przedstawiono analizę powierzchni i zasięgu zlewni rzeki Silnicy oraz jej sześciu zlewni cząstkowych wyznaczonych metodami GIS w trzech wariantach z użyciem NMT $\mathrm{z}$ projektu ISOK o rozdzielczości $1 \mathrm{~m}$, bazy danych obiektów topograficznych (BDOT) w skali 1: 10000 oraz geodezyjnej ewidencji sieci uzbrojenia terenu (GESUT). Przeanalizowano także różnice zasięgu zlewni Silnicy wyznaczonego na podstawie mapy topograficznej w skali 1: 10 000, a także pozyskanego z mapy podziału hydrograficznego Polski (MPHP) 1 : 10 000. W każdym $\mathrm{z}$ wariantów przeprowadzonego modelo- wania zmianom ulegał przebieg granic badanych zlewni, co spowodowało zarówno zmiany ich areału, jak i zasięgu przestrzennego. Najlepsze rezultaty dało wykorzystanie procedur wyznaczania granic zlewni w GIS z użyciem NMT oraz skorygowanych baz BDOT i GESUT. W tym przypadku zasięgi zlewni pokrywały się z rzeczywistymi zasięgami odwodnienia. Tradycyjne metody wyznaczania działów wodnych z wykorzystaniem mapy topograficznej oraz istniejące źródła danych w postaci MPHP w skali 1 : 10000 były mało dokładne w stosunku do całej zlewni Silnicy i nieprzydatne do wyznaczenia małych zlewni cząstkowych w centrum Kielc.

\section{Summary}

The use of GIS methods in urban catchment drainage divides delineation on example of the Kielce city. The paper presents the analysis of the area and reach of the Silnica river catchment and its six subcatchments delineated using GIS in three different variants: DEM (from Computerized Information System of Country Protection project; Polish: ISOK) in one-meter resolution, the Database of Topographic Objects (Polish: BDOT) in $1: 10000$ scale and the Geodetic Utilities Network System (Polish: GESUT). A topographic map in $1: 1000$ scale was also compared with the Map of Hydrographic Division of Poland (Polish: MPHP) and the differences in the catchment reach resulting from this comparison were also examined. The course of delineated drainage divides varied in each variant resulting in differences in the area and reach of the analyzed catchments. The best results in urban catchments delineation were obtained in GIS using DEM and corrected vector data from BDOT and GESUT databases. In this case, the catchments' reach overlapped with the existing drainage network. Traditional methods with the use of topographic maps and data from MPHP 
$1: 10000$ scale proved to be less accurate as far as the reach of the Silnica river catchment was concerned and were useless in delineating the Silnica sub-catchments in Kielce city center.

\section{Author's address:}

Grzegorz Wałek

Uniwersytet Jana Kochanowskiego w Kielcach Instytut Geografii

ul. Świętokrzyska 15, 25-406 Kielce

Poland

e-mail: grzegorz.walek@ujk.edu.pl 